\title{
Pentingnya Belajar Dalam Perjanjian Lama
}

\section{Hendro Hariyanto Siburian ${ }^{1 *}$}

\author{
${ }^{1)}$ Dosen Sekolah Tinggi Teologi Tawangmangu \\ ${ }^{*}$ Penulis korespondensi: hendropertama@gmail.com
}

\begin{abstract}
Abstrak
Sejak lahir manusia mengalami proses tumbuh kembang fisik, jiwa, dan akal pikiran yang disertai dengan kegiatan belajar. Kegiatan belajar juga terjadi dalam pendidikan agama Kristen, di mana yang menjadi objek belajar adalah Firman Tuhan. Oleh karena itu dalam penelitian ini, peneliti menerapkan pendekatan eksposisi kata belajar yang terdapat di Perjanjian Lama, sehingga mendapatkan makna kata belajar.

Kata belajar dalam Perjanjian Lama ditulis dalam dua kata yaitu; pertama, kata לְֵ lamad yang bermakna belajar merupakan proses mendalami, memahami sampai mampu melakukan atau menerapkannya dalam kehidupan. Kedua, kata לְֵ lahag yang bermakna belajar adalah proses mendapatkan pengetahuan saja, sehingga dalam pendidikan agama Kristen, proses belajar yang dilakukan peserta didik jangan hanya sampai pada mendapatkan pengetahuan saja (firman Tuhan), melainkan harus sampai kepada menerapkan atau melakukannya (firman Tuhan) dalam kehidupan sehari-hari.
\end{abstract}

Kata kunci: Belajar, Perjanjian Lama, pendidikan agama Kristen

\section{Abstract}

From birth humans experience the process of growth and development of physical, mental, and mind accompanied by learning activities. Learning activities also take place in Christian religious education, where the object of learning is the Word of God. Therefore in this study, researchers applied the word learning exposition approach contained in the Old Testament, so as to get the meaning of the word learning.

The word learning in the books of the Old Testament is written in two words namely; First, the word לביז "lamad" which means learning is a process of learning, understanding and being able to do or apply it in life. And secondly, the word לה la hag which means learning is the process of gaining knowledge alone. So that in Christian religious education, the 
learning process carried out by students should not only get to the knowledge (the word of God), but must come to apply or do it in everyday life (the word of God).

Keywords: learn, Christian education

\section{Pendahuluan}

Secara alamiah manusia mengalami pertumbuhan dan perkembangan. Proses tersebut dimulai sejak dalam kandungan sampai pada akhir hidupnya. Manusia mengalami proses tahap demi tahap baik dalam pertumbuhan secara kognitif, afektif dan psikomototik (tubuh dan jiwa). Pertumbuhan dan perkembangan yang normal akan terlihat bila ketiga aspek tersebut mengalami peningkatan. Perkembangan/peningkatan ketiga aspek tersebut didapat dari proses belajar. Artinya dalam segala aspek kehidupan manusia setiap hari, tidak akan terlepas dari kegiatan belajar. Baik aktivitas yang dilakukan sendiri maupun yang dilakukan berkelompok, tentu ada aktivitas belajarnya.

Kegiatan belajar merupakan implementasi manusia sebagai ciptaan Tuhan yang mulia. Dalam Perjanjian Lama ditulis bahwa manusia diciptakan lebih mulia dari segala ciptaan Allah; manusia diberikan potensipotensi dalam dirinya seperti kemampuan berpikir, berkomunikasi, merasakan, memperhatikan, dan bersosialisasi. Manusia diciptakan oleh Tuhan dengan tubuh, jiwa dan roh. Selain diberi roh (Ibr. nefes hayyah) oleh Allah (Kej. 2:7), manusia juga diperlengkapi dengan akal dan pikiran. ${ }^{1}$ Akal dan pikiran diberikan kepada manusia untuk dikembangkan dan dipergunakan untuk kelangsungan hidup manusia tersebut.

Dengan akal dan pikiran, manusia mampu belajar berbagai hal untuk mengembangkan diri dan berusaha memperoleh kepandaian atau ilmu. Karena aktivitas belajar itulah yang membedakan manusia dengan makhluk lain seperti binatang dan tumbuhan. Aktivitas belajar pula yang mengantarkan seorang manusia menjadi berilmu, yang selanjutnya memosisikan manusia menjadi makhluk yang paling mulia di antara makhluk yang ada di muka bumi ini. Melalui belajar, manusia mampu bertahan hidup dan mampu memenuhi apa yang menjadi kebutuhan

${ }^{1}$ Junihot M. Simajuntak, Belajar Sebagai Identitas dan Tugas Gereja, Jurnal Jaffray, Vol. 16, No. 1, April 2018, 7. 
hidupnya. Manusia bisa mengembangkan budayanya, dan karena belajar pula, manusia bisa menguasai alam dan bisa mengubah wajah dunia ini.

Pendidikan agama Kristen hadir untuk mengembangkan dan meningkatkan potensi spiritual dan membentuk peserta didik agar menjadi manusia yang beriman dan bertaqwa kepada Tuhan Yesus Kristus dan berkarakter Kristus. Namun kenyataannya, hasil pendidikan agama Kristen belum sesuai dengan harapan. Masih banyak peserta didik PAK yang hanya sebatas mengetahui kebenaran-kebenaran Firman Tuhan tanpa melakukannya dalam kehidupan sehari-hari. Kehidupan yang beriman dan bertaqwa kepada Tuhan Yesus belum tampak dalam perilaku keseharian kehidupan peserta didik, misalnya masih ada peserta didik yang hidup semaunya atau pergaulan bebas, melawan kepada guru dan orang tua, masih malas datang beribadah, dan masih banyak masalah-masalah lainnya. Sehingga perlu penegasan kembali dalam proses belajar peserta didik pendidikan agama Kristen, belajar bukan semata-mata untuk mendapatkan pengetahuan tentang agama, melainkan menghidupinya. Penelitian ini bertujuan untuk menjawab pertanyaan: bagaimana konsep belajar dalam Perjanjian Lama dan bagaimana implementasinya bagi Pendidikan Agama Kristen masa kini.

\section{Metode Penelitian}

Metode penelitian adalah rangkaian kegiatan dan cara pelaksanaan penelitian yang dijalankan oleh penulis. ${ }^{2}$ Penelitian ini menggunakan metode kualitatif. Bentuk pendekatan yang digunakan adalah pendekatan eksposisi kata belajar dari Perjanjian Lama. Analisis data penelitian yang digunakan adalah deskriptif analisis. Penelitian bersifat analitis yaitu mengadakan pengkajian berdasarkan analisis dokumen. ${ }^{3}$ Peneliti mengeksposisi kata belajar dari Perjanjian Lama, melakukan analisis dan penafsiran terhadap kata belajar. ${ }^{4}$ Buku-buku literatur digunakan sebagai

${ }^{2}$ Andreas B. Subagyo, Pengantar Riset Kuantitatif dan Kualitatif (Bandung: Yayasan Kalam Hidup, 2004), 52.

${ }^{3}$ Nana Syaodih Sukmadinata, Metode Penelitian Pendidikan (Bandung: PT Remaja Rosdakarya, 2008), 65.

${ }^{4}$ Hendro Hariyanto Siburian, "Implementasi Kesatuan dan Kerendahan Hati Jemaat Berdasarkan Filipi 2:1-11 Di Kalangan Jemaat Gereja Pengharapan Allah Indonesia Surakarta," Sekolah Tinggi Teologia Berita Hidup (Sekolah Tinggi Teologia Berita Hidup, 2018), 92, https://doi.org/10.31219/osf.io/adfbs. 
penunjang analisis kata belajar di Perjanjian Lama. Teknik analisis data melalui mengelaborasi semua data ke dalam rangkuman kemudian ditarik kesimpulan dari kata belajar di Perjanjian Lama sehingga dapat diaplikasikan di dalam dunia pendidikan agama Kristen di masa kini.

\section{Pembahasan}

\section{Dasar Pemikiran Belajar Dalam Pendidikan}

Sejak lahir setiap orang telah memiliki potensi dan naluri. Potensi dan insting tersebut tidak serta merta berkembang dengan sendirinya melainkan adanya campur tangan manusia lain. Oleh sebab itu perlu adanya kegiatan belajar untuk membantu setiap orang mengembangkan semua potensinya. Dalam pertumbuhannya, manusia juga mengalami perkembangan otak. Otak merupakan mesin penggerak segala fungsi dan aktivitas tubuh manusia. Kecerdasan, kreativitas, emosional, dan ingatan diatur oleh otak. ${ }^{5}$ Otak bekerja karena adanya stimulus atau rangsangan sehingga memberi perintah untuk melakukan suatu aktivitas terhadap tubuh. Termasuk dalam hal belajar, otak menjadi pusat terjadinya kognitif, afektif dan psikomotorik.

Penting memahami arti belajar, supaya terhindar dari pemahaman yang keliru tentang kata belajar. Belajar bukan perubahan kemampuan yang disebabkan kematangan, pertumbuhan, dan perkembangan seperti seorang anak yang semakin mampu berdiri, berjalan dan perkembangan fisiknya. Bahkan sebagian orang menganggap belajar hanya semata-mata kegiatan transfer ilmu pengetahuan saja. Namun dalam prakteknya lebih kompleks. Oleh karena itu, perlu dipaparkan konsep belajar menurut para ahli, sebagai berikut:

Belajar merupakan aktivitas manusia yang sangat vital dan secara terus-menerus akan dilakukan selama manusia tersebut masih hidup. Melalui belajar manusia dapat mengembangkan seluruh potensi yang ada dalam dirinya. Morgan dalam M. Thobroni mengatakan belajar adalah setiap perubahan yang relatif menetap dalam tingkah laku yang terjadi sebagai suatu hasil latihan atau pengalaman. ${ }^{6}$ Belajar dapat diartikan sebagai perubahan yang relatif permanen dari pengembangan potensi dalam diri

${ }^{5}$ Yusra Firdaus, https://hellosehat.com/hidup-sehat/tahapan-perkembangan-otakmanusia/, diakses pada 20 Februari 2019, pukul 9:19 WIB.

${ }^{6}$ Thobroni, Belajar dan Pembelajaran (Teori dan Praktik), (Yogyakarta : Ar-Ruzz Media, 2016), 18. 
subjek belajar melalui praktik. Secara umum belajar merupakan hasil dari interaksi antara stimulus dan respon. Seseorang dianggap telah belajar sesuatu jika dia dapat menunjukkan perubahan perilaku seperti sesuatu tersebut. Belajar berarti ada materi ajar yang diterima peserta didik dan peserta didik mampu mengungkapkannya kembali dalam bentuk tanggapan dan perilaku.

Dalam belajar harus ada stimulus dan respon. Dalam kontek pembelajaran stimulus adalah rangsangan yang guru berikan kepada peserta didik, sedangkan reaksi atau respon dalam bentuk tanggapan siswa terhadap stimulus yang diberikan oleh guru. Proses yang terjadi antara stimulus dan respon penting untuk dicatat karena tidak dapat diamati dan tidak dapat diukur, yang dapat diamati adalah stimulus dan respon. Oleh karena itu, materi yang diberikan atau diajarkan (stimulus) oleh guru dan apa yang diterima (respon) oleh siswa harus dapat diamati dan diukur.

Menurut Kamus Besar Bahasa Indonesia, belajar adalah berusaha memperoleh kepandaian atau ilmu; berlatih; berubah tingkah laku atau tanggapan yang disebabkan oleh pengalaman. ${ }^{7}$ Ada proses yang dilakukan untuk memperoleh kepandaian/ilmu, sampai terjadinya perubahan perilaku dan cara berpikir. Menurut Syaiful Bahri Djamarah, belajar adalah serangkaian kegiatan jiwa raga untuk memperoleh suatu perubahan baik tingkah laku maupun pengetahuan sebagai hasil dari pengalaman individu dalam interaksi dengan lingkungannya yang menyangkut kognitif, afektif, dan psikomotor. Menurut Robert Gagne, belajar adalah suatu proses untuk memperoleh motivasi dalam pengetahuan, keterampilan, kebiasaan dan tingkah laku. ${ }^{8}$ Lebih lanjut Gagne menjelaskan bahwa belajar merupakan terjadinya proses stimulasi yang memengaruhi subjek belajar sehingga perbuatannya berubah dari waktu ke waktu. ${ }^{9}$ Jadi belajar juga dipengaruhi oleh faktor-faktor di luar diri dan dari dalam diri peserta didik.

Menurut Robert Gagne, ada lima kategori yang dipelajari manusia: ${ }^{10}$

1) Keterampilan Motorik (motor skill) yaitu koordinasi gerakan-gerakan badan. Keterampilan ini juga membutuhkan proses belajar, di mana

${ }^{7}$ http://kbbi.web.id, diakses pada 12 Januari 2019, pukul 11:23 WIB.

${ }^{8}$ Djamarah, S.B., Psikologi Belajar, (Yogyakarta : Rineka Cipta, 2000), 22.

${ }^{9}$ Thobroni, 18.

${ }^{10}$ Slameto, Belajar dan Faktor-Faktor Yang Mempengaruhinya, (Jakarta: PT Rineka Cipta, 1995), 14 
seseorang melatih motoriknya untuk melakukan sesuatu. Gerakangerakan yang dihasilkan tidak hanya bergerak tetapi ada tujuan yang ingin dicapai. Keterampilan motorik sangat menunjang aktivitas seseorang.

2) Informasi Verbal, yaitu mejelaskan segala sesuatu dengan berbicara, menulis, dan mengambar. Manusia juga mempelajari informasi verbal, di mana informasi ini menjadi sarana komunikasi yang dibutuhkan dalam segala interaksi manusia. Seseorang harus belajar bagaimana berbicara, menulis dan mengambar. Informasi verbal merupakan simbol-simbol yang harus dimengerti dan dipahami oleh seseorang dan mampu menuangkannya dalam bentuk bahasa, tulisan dan gambar.

3) Kemampuan intelektual, yaitu kemampuan menggunakan dan mengembangkan simbol-simbol dalam mengadakan interaksi dengan dunia luar. Kemampuan intelektual didapatkan dari proses belajar simbol-simbol dan mengembangkannya sedemikian rupa untuk keperluan interaksinya.

4) Strategi kognitif, yaitu belajar mengingat dan berpikir memerlukan organisasi keterampilan yang internal. Salah satu bukti seseorang dikatakan belajar dapat dilihat dari perkembangan kognitifnya, di mana seseorang yang belajar akan mengalamai perkembangan secara kognitif, yang dibuktikan adanya kemampuan mengingat dan berpikir yang sistematis.

5) Sikap, yaitu sikap belajar yang penting dalam proses belajar. Hasil dari proses belajar salah satunya munculnya sikap yang benar. Sebab seseorang yang berkembang secara kognitif akan mampu berpikir dan mampu menentukan sikap yang benar dalam meresponi segala sesuatu.

Jadi salah satu pertanda bahwa seseorang telah belajar adalah adanya perubahan tingkah laku dalam dirinya. Perubahan tingkah laku tersebut berhubungan dengan perubahan yang bersifat pengetahuan (kognitif), keterampilan (psikomotor) maupun yang menyangkut nilai dan sikap (afektif) pada diri seseorang. Belajar tidak hanya meliputi mata pelajaran, tetapi juga penguasaan, kebiasaan, persepsi, kesenangan, kompetensi, penyesuaian sosial, bermacam-macam keterampilan, dan cita-cita.

Menurut Junihot Simajuntak, belajar adalah sebagai suatu proses perubahan yang membutuhkan energi, ruang, dan waktu, serta melibatkan keseluruhan pribadi manusia (pikiran, perasaan, kemampuan, roh, dan 
tubuh), mencakup aspek internal dan eksternal. ${ }^{11}$ Proses belajar membutuhkan keterlibatan secara utuh dari subjek belajar. Semua organ subjek belajar saling terkait dalam menerima stimulus dan memberi respon. Sehingga proses belajar menghasilkan perubahan perilaku dan cara pandang si subjek belajar.

Arthur S. Reber, membagi kata belajar ke dalam dua pengertian yaitu, Pertama, belajar adalah: proses memperoleh pengetahuan. Pengertian tersebut lebih sering dipakai dalam pembahasan psikologi kognitif, yang oleh sebagian ahli dipandang kurang mewakili karena tidak mencantumkan pencapaian dari keterampilan non kognitif. Kedua, belajar adalah suatu perubahan kemampuan menanggap yang relatif/tidak mutlak selamanya sebagai hasil latihan yang dipertajam. ${ }^{12}$. Menurut H. Mahmud, belajar adalah diperolehnya kebiasaan-kebiasaan, pengetahuan, dan sikap baru. ${ }^{13}$ Perubahan ini ditandai terjadinya perubahan prilaku yaitu perubahan terjadi secara sadar, perubahan bersifat kontinu dan fungsional, perubahan bersifat positif dan aktif.

\section{Faktor-Faktor yang Mempengaruhi Proses Belajar}

Keberlangsungan proses belajar sangat dipengaruhi oleh berbagai macam faktor. Baik itu yang datang dari dalam diri subjek belajar, dari luar diri subjek belajar dan termasuk metode belajar. Jadi keberhasilan suatu proses belajar dan pembelajaran tidak terlepas dari faktor-faktor yang memengaruhinya.

Menurut Mahmud, ada tiga faktor yang memengaruhi belajar, di antaranya: ${ }^{14}$

\section{Faktor Individual}

Faktor internal subjek belajar, seperti kondisi jasmani dan rohani. Aspek jasmani atau fisiologis berbicara tetang berfungsinya semua organ tubuh subjek belajar dengan sesuai fungsinya. Aspek psikologis di antaranya psikis dan esensial seperti tingkat kecerdasan, sikap, bakat, 2016. 47.

${ }^{11}$ Junihot S., Psikologi Pendidikan Agama Kristen, Yogyakarta: Penerbit ANDI,

${ }^{12}$ Arthur S. Reber, The Penguin Dictionary of Psychology: edisi 2010 terjemahan, (New York: Penguin Book, 2001), 53.

${ }^{13}$ H. Mahmud, Psikologi Pendidikan, (Bandung : CV Pustaka Setia, 2012), 61.

${ }^{14}$ H. Mahmud, 93-104. 
minat, dan motivasi. Keberlangsungan proses belajar sangat dipengaruhi faktor pribadi dari subjek belajar. Proses belajar akan terlaksana jika subjek belajar memiliki keinginan atau dorongan dari dalam dirinya untuk belajar.

2. Faktor Eksternal

Faktor eksternal di antaranya lingkungan sosial (lingkungan sekolah dan masyarakat), termasuk di dalamnya, hubungan dengan guru, orangtua, dan masyarakat. Lingkungan nonsosial (gedung sekolah, alatalat sekolah, keadaan cuaca, dan waktu belajar). Faktor eksternal ini merupakan faktor pendukung terlaksananya proses belajar. Faktor ini juga mempengaruhi tingkat keberhasilan proses belajar dari subjek belajar.

3. Faktor Struktural

Faktor struktural atau sering disebut pendekatan (metode) belajar. Pendekatan belajar berpengaruh terhadap tingkat keberhasilan proses belajar. Pendekatan pembelajaran misalnya: ceramah, praktikum, dll. Selain itu ada aspek gaya belajar (gaya belajar visual, gaya belajar auditorial, dan gaya belajar kinestesis). Faktor struktural juga merupakan faktor pendukung terlaksananya proses belajar, faktor struktural menjadi salah satu penentu keberhasilan proses belajar. Dalam faktor struktural terdapat metode dan media ajar yang dapat digunakan untuk menunjang terlaksanannya proses belajar.

Senada dengan Mahmud, M. Ngalim Purwanto membagi tiga faktor yang mempengaruhi belajar: ${ }^{15}$

1. Faktor Internal

Faktor internal merupakan keadaan jasmani seseorang/peserta didik. Keadaan jasmani tersebut berupa kematangan dan pertumbuhan, inteligensi/kecerdasan, latihan, motivasi dan kepribadian, dan keadaan rohani peserta didik.

2. Faktor Eksternal

Faktor eksternal merupakan kondisi lingkungan di sekitar peserta didik/faktor sosial. Yang termasuk dalam faktor kondisi lingkungan di antaranya; kondisi keluarga, guru, media, lingkungan di sekitar dan faktor motivasi sosial.

${ }^{15}$ M. Thobroni, 28-29. 
3. Faktor Pendekatan Pelajar

Faktor pendekatan pelajar merupakan strategi dan metode belajar yang digunakan peserta didik untuk menyampaikan materi-materi pelajaran kepada peserta didik dengan cara melakukan pendekatan kepada peserta didik secara personal atapun kelompok.

Ditinjau dari faktor pendekatan belajar, terdapat tiga pendekatan belajar menurut Biggs dalam Junihot: ${ }^{16}$

1. Pendekatan permukaan/ bersifat lahiriah (Surface), yaitu kecenderungan belajar peserta didik terjadi karena adanya dorongan dari luar (ekstrinsik) dirinya. Biasanya ada tekanan dari luar, dan pada umumnya menyebabkan peserta didik tidak sungguh-sungguh dalam belajar (asalasalan).

2. Pendekatan mendalam (deep), yaitu kecenderungan belajar peserta didik karena adanya dorongan dari dalam (instrinsik). Biasanya peserta didik menyukai materi tersebut sehingga peserta didik dengan serius dalam belajar.

3. Pendekatan pencapaian prestasi tinggi (achieving), yaitu kecenderungan belajar siswa karena adanya dorongan untuk mewujudkan ego enhancement yaitu ambisi pribadi yang besar dalam meningkatkan prestasi setinggi-tingginya.

Jadi belajar adalah perubahan tingkah laku sebagai hasil dari perbuatan belajar yang terjadi secara sadar, bersifat berkelanjutan dan sesuai fungsinya, bersifat positif (perubahan jadi baik) dan aktif (penerapan), bersifat konstan, memiliki tujuan yang jelas, serta mencakup seluruh aspek tingkah laku subjek belajar. Berhasil atau tidaknya proses belajar sangat dipengaruhi oleh faktor individu, faktor luar individu dan faktor pendekatan belajar.

\section{Konsep Belajar dalam Perjanjian Lama}

Eksposisi Kata Belajar dalam Perjanjian Lama

Kata belajar dalam tulisan ini diambil dari Perjanjian Lama Terjemahan Baru (LAI; TB) yaitu dalam Ulangan 14:23;17:19;18:9; 31:12; 31:13, Mazmur 106:35, 119:7; 71, 73, Pengkhotbah. 12:12, Yesaya. 1:17; 2:4; 26:9, 10; Yeremia. 12:16; Yehezkiel. 19:3, 6; Mikha. 4:3. Jadi

${ }^{16}$ Junihot, 49-50. 
pembahasan artikel ini akan fokus dengan kata "belajar" dalam kitab-kitab tersebut.

Para penulis Perjanjian Lama memiliki tujuan dan maksud-maksud dalam setiap tulisannya. Termasuk kata "belajar" berulang-ulang ditegaskan di 6 kitab Perjanjian Lama tersebut, sehingga sangat penting untuk menggali makna kata "belajar" dan mengetahui tujuan dari setiap penggunaan kata tersebut dalam setiap teks PL, sehingga dapat diimplementasikan dalam proses pendidikan agama Kristen masa kini.

Dalam Perjanjian Lama ada kata yang mengambarkan kegiatan belajar dan mengajar. Secara khusus kata belajar dalam bahasa Ibrani לִ lamad (law-mad') disebutkan sebanyak 17 kali dalam Perjanjian Lama dan kata לבהג (la hag) disebutkan 1 kali dalam Perjanjian Lama. Jadi kata belajar dalam kitab-kitab Perjanjian Lama disebutkan dengan kedua kata tersebut.

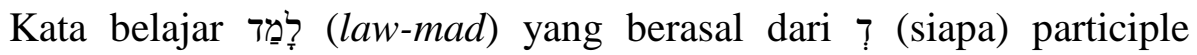
conjunction, לִַמִ (to learn artinya untuk mempelajari) verb qal imperfect $2^{\text {nd }}$ person masculine singular. ${ }^{17}$ Kata לִֵמֵ (law-mad) menurut KJV, NAS, NIV, RSV diterjemahkan menjadi "learn" (belajar). Kata belajar לִ (law-mad) ditemukan dalam Ulangan 14:23; 17:19; 18:9; 31:12; 31:13, Mazmur 106:35, 119:7; 71, 73, Yesaya. 1:17; 2:4; 26:9, 10; Yeremia. 12:16; Yehezkiel. 19:3, 6; dan Mikha. 4:3. Sedangkan di dalam pengkhotbah 12:12, kata belajar menggunakan kata benda לבהג (la hag) berasal dari kata ? particle conjunction לִ לַה noun common masculine singular absolute. Dalam bahasa Inggris diterjemahkan menjadi study, i.e. devotion to books. Menurut KJV, NIV dan RSV menerjemahkannya menjadi study (belajar), sedangkan NAS menerjemahkannya devotion (kesetiaan/ketaatan). Dalam konteks Pengkhotbah 12:12, kata belajar di sini memiliki pengertian berbeda dengan kata belajar di kitab-kitab Perjanjian Lama lainnya dalam hal objek belajar. Kata belajar di sini memiliki pengertian bahwa belajar merupakan kegiatan seseorang dalam mendapatkan hanya sebatas pengetahuan yang didapat dari buku-buku. Subjek belajar memberi diri dengan kesetiaan atau lebih mengagungkan pengetahuan dari pada Tuhan. Objek belajar hanya untuk dipahami dan ditaati bukan untuk tujuan memuliakan Tuhan, melainkan hanya untuk kepuasan diri sendiri.

${ }^{17}$ BibleWorks versi 8 copyright (c) 2009 for Windows. Semua tulisan Ibrani diambil dari aplikasi Bible Works versi 8. 
Kata "belajar" dalam (Ul. 14:23;17:19;18:9; 31:12; 31:13, Maz. 106:35, 119:7; 71, 73, Yes. 1:17; 2:4; Pkh. 12:12, Yes. 26:9, 10; Yer. 12:16; Yeh. 19:3, 6; Mik. 4:3) berasal dari kata לִ (law-mad) berarti to learn. teach, exercise in 1a) (Qal) to learn 1b) (Piel) to teach 1c) (Pual) to be taught, be trained, menjelaskan kegiatan belajar yang dilakukan. Proses belajar menjadi satu kebiasaan (berulang-ulang) yang dilakukan oleh subjek belajar. Dalam konteks ini, objek belajar merupakan ketetapan Tuhan.

Jika kita melihat dari setiap bentuk kata kerja dalam bahasa Ibrani, kata law-mad dapat dijelaskan sebagai berikut:

Pertama, bentuk kata kerja aktif (Qal) to learn artinya untuk mempelajari, menggali, mencari tahu dan mendalami. Kata kerja "mempelajari" menunjukkan ada kegiatan dari seseorang untuk mengetahui, memahami sesuatu hal. Artinya ada dorongan dari dalam diri seseorang untuk menemukan, mengetahui, dan memahami/mendalami dari apa yng dipelajari. Kata belajar di sini juga disertai dengan kegiatan fisik (exercise in) artinya ada kegiatan latihan fisik/badan dalam proses belajar. Belajar juga berkaitan dengan aktivitas fisik. Di mana fisik juga dapat dilatih sedemikian rupa untuk mencapai atau mendukung tujuan yang dirancangkan.

Kedua, bentuk kata kerja aktif intensif (Piel) to teach (kegiatan yang dilakukan subjek belajar secara terus-menerus). Kata belajar ditinjau dari bentuk kata kerja aktif intensif memiliki pengertian bahwa subjek belajar juga harus berkembang menjadi pengajar. Pengetahuan dan pengalaman yang didapatkan tidak hanya berhenti untuk diri sendiri si subjek belajar, melainkan ia mengajarkannya kepada orang lain.

Ketiga, bentuk kata kerja pasif (Pual) to be taught, be trained, artinya ada kegiatan/tindakan mengajarkan dan melatih secara terus-menerus kepada seseorang yang belajar. Proses belajar tidak berhenti begitu saja, melainkan ada latihan yang dilakukan secara terus-menerus. Belajar tidak hanya mengisi pemahaman kognitif, melainkan juga terus dikembangkan dalam ranah psikomotorik dan efektifnya.

Dalam proses belajar tidak terlepas dari yang namanya menyampaikan pengetahuan, pelatihan dan peniruan. Pada dasarnya tujuan orang melakukan aktivitas belajar salah satunya untuk regenerasi. Dalam hal ini seseorang belajar sesuatu, sampai ia dapat mengajarkan kembali apa yang telah dipelajarinya. Jadi dalam Perjanjian Lama, belajar merupakan suatu kegiatan yang melibatkan keseluruhan aspek kehidupan subjek belajar. 
Subjek belajar bukan semata-mata untuk memperoleh pengetahuan atau pengalaman, akan tetapi juga sampai taraf memahami dan melakukan tindakan. Perubahan perilaku dan cara pikir merupakan hasil belajar. Hasil belajar mengharuskan seseorang menghidupinya. Dalam konteks kata belajar dalam Perjanjian Lama, seseorang dituntut untuk belajar sampai paham secara mendalam. Secara khusus dalam teks Alkitab, seseorang belajar kebenaran Firman Tuhan dan melakukannya dalam kehidupan sehari-hari.

Dari pembahasan di atas, makna kata belajar dalam Perjanjian Lama diartikan menjadi; pertama, kata belajar לִֵֶַ (law-mad) diterjemahkan ke dalam bahasa Inggris menjadi to learn. teach, exercise in artinya untuk mempelajari, menggali, mengajar, mencari tahu dan mendalami atau latihan (termasuk latihan fisik). Kegiatan belajar yang biasa dilakukan dalam kehidupan sehari-hari untuk mencari, mengetahui, memahami sesuatu, serta melatih dirinnya (fisik) sehingga mampu menerapkannya dalam kehidupan serta mampu mengajarkan kepada orang lain. Dalam keseharian belajar menjadi gaya hidup, baik belajar dari interaksi sosial maupun belajar dari buku-buku dan kitab-kitab suci. Kedua, kata לָּג (la hag) artinya study, devotion to books yang diterjemahkan menjadi belajar untuk mendapatkan pengetahuan dari buku-buku tanpa ada latihan fisik.

\section{Makna Belajar dalam Perjanjian Lama}

Dari Perjanjian Lama kata "belajar" dalam bahasa Ibrani ada dua kata yang di gunakan yaitu yang pertama menggunakan kata לִ (law-mad) לבהג kalam bahasa Inggris learn (belajar) dan kata kedua menggunakan kata (la hag) dalam bahasa Inggris diterjemahkan menjadi Study (belajar). Kata "belajar" dari kedua kata ini memiliki persamaan dalam tujuan yaitu untuk mendapatkan sesuatu. Akan tetapi berbeda dalam hal proses dalam mendapatkan sesuatu.

Dalam bahasa Inggris definisi kata learn dan study memiliki makna yang berbeda dalam prosesnya dan objek belajarnya. Defnisi kedua kata ini menurut Oxford Dictionary. ${ }^{18}$ study/'stıdi/The devotion of time and attention to gaining knowledge of an academic subject, especially by means

18 https://id.oxforddictionaries.com/terjemahkan/inggris-indonesia/learn, diakses pada 8 Mei 2017. 
of books: the study of English; an application to continue full-time Study. Kata learn /lo:n/Gain or acquire knowledge of or skill in (something) by study, experience, or being taught: they'd started learning French; she is learning to play the piano; we learn from experience

Kata study, memiliki tujuan memperoleh pengetahuan (knowledge) melalui akademik dan buku-buku. Kata study lebih kepada pendidikan formal dan sistematis, sedangkan kata learn tidak hanya bertujuan mendapat knowledge (pengetahuan), tetapi juga skill (keterampilan/keahlian). Jadi di dalam proses learn juga terdapat study, ditambah pengalaman hidup, serta diajarkan oleh orang lain. ${ }^{19}$

Jadi dapat disimpulkan bahwa dalam Perjanjian Lama makna kata belajar memiliki dua pengertian, sebagai berikut: ${ }^{20}$

1. Kata לִֵ (law-mad) Learn (Belajar)

Kata learn terdapat dalam Ulangan 14:23;17:19;18:9; 31:12; 31:13, Mazmur 106:35, 119:7; 71, 73, Yesaya. 1:17; 2:4; 26:9, 10; Yeremia. 12:16; Yehezkiel. 19:3, 6; Mikha. 4:3. Dari seluruh kitab di PL yang menerangkan kata "belajar" atau learn hanya terdapat di kitab Ulangan, Mazmur, Yesaya, Yeremia, Yehezkiel dan Mikha.

Dalam Ulangan 14:23;17:19;18:9; 31:12; 31:13 kata belajar (learn) memiliki pengertian bahwa subjek belajar berusaha mempelajari, menggali, memahami objek belajar (Firman Tuhan) dalam sepanjang kehidupannya. Subjek belajar tidak hanya sebatas memahami apa yang menjadi objek belajar melainkan juga melatih fisiknya untuk melakukan apa yang dipelajari. Objek belajar dalam teks tersebut menjadi sebuah peringatan untuk dilakukan dengan baik dan tekun, sehingga subjek belajar sampai terbiasa (menjadi gaya hidup) untuk memahami dan melakukan objek belajar, terutama tentang hal-hal yang menjadi kehendak Allah. ${ }^{21}$ Belajar (ketetapan Tuhan) menjadi kebiasaan subjek belajar dan bertujuan untuk memuliakan Tuhan.

\footnotetext{
${ }^{19} \mathrm{http} / / /$ www.kompasiana.com/audiaaa/studying-is-bored-learning-is fun_55c3175bac92737814471a0a. Diakses pada 8 Mei 2017.

${ }^{20}$ Hendro Hariyanto Siburian dan Arif Wicaksono, "Makna Belajar Dalam Perjanjian Lama dan Implementasinya Bagi PAK Masa Kini," Fidei: Jurnal Teologi Sistemati dan Praktika 2, no. 2 (2019): 219.

${ }^{21}$ Donal Guthrie, Tafsiran Alkitab Masa Kini 1 (Jakarta: Yayasan Komunikasi Bina Kasih/OMF, 1998), 325.
} 
Kata belajar dalam Mazmur 106:35, 119:7, 71, 73, diperoleh makna sebagai kegiatan yang biasa dilakukan. ${ }^{22}$ Belajar apa yang menjadi ketetapan Allah. Pasal 106:35 bangsa Israel ketika masuk tanah Kanaan mereka belajar (terbiasa) cara-cara bangsa kafir dalam bekerja dan hal ini berlawanan dengan kehendak Tuhan. Selebihnya dalam kitab Mazmur, kata belajar (kata kerja) memiliki makna supaya bangsa Israel terbiasa dan sadar akan ketetapan Tuhan dan bergantung kepada penciptanya. Belajar menjadikan bangsa Israel sadar dan bersyukur kepada Tuhan sang pencipta. Dari makna tersebut dapat disimpulkan bahwa kegiatan belajar harus dilakukan secara sadar. Sadar akan apa yang menjadi objek belajar, sehingga mampu memahami objek belajar (dalam teks yaitu ketetapan Tuhan) tersebut dan sampai taraf mampu melakukan dalam kehidupan apa yang dipelajari.

Lebih lanjut kata belajar dalam kitab Yesaya 1:17; 2:4; 26:9-10, memiliki pengertian belajar (learn) dari pengalaman hidup yang dialami oleh bangsa Israel. Bangsa Israel belajar bahwa Tuhan itu adalah hakim yang adil dan Tuhan yang akan menepati janji-Nya. ${ }^{23}$ Senada dengan itu kata belajar dalam kitab Yeremia 12:16 juga menggunakan kata learn yang bermakna bangsa Israel harus belajar (mempelajari dengan sungguh-sungguh gaya hidup umat Tuhan) dari pengalaman hidup mereka ketika dipimpin oleh Allah, sehingga mereka mendapat keselamatan dan pembebasan.

Makna belajar dalam Yehezkiel 19:3,6 belajar merupakan latihan atau terlatih dalam melakukan sesuatu, sedangkan dalam kitab Mikha 4:3 kata belajar bermakna bahwa bangsa-bangsa tidak akan belajar (belajar atau melatih fisik) perang. Hal ini disebabkan Tuhan Allah telah hadir sebagai hakim dan raja damai.

Jadi dari makna kata belajar dalam kitab-kitab tersebut menunjukkan proses belajar menghasilkan perubahan perilaku dalam diri seseorang yang belajar, baik secara kognitif, afektif, psikomotorik dan spritual.

\section{Kata לִ להג (laohag) Study (belajar)}

\footnotetext{
${ }^{22}$ Donal Guthrie, 244.

${ }^{23}$ Andrew E. Hill dan John H. Walton, Survey Perjanjian Lama (Malang: Penerbit Gandum Mas, 2008), 528-529.
} 
Kata belajar yang menggunakan kata לִ לָהג (la hag) dalam bahasa Inggris diterjemahkan study terdapat dalam Pengkhotbah 12:12.

Kata "belajar" dalam Pkh. 12:12, menggunakan kata להב (la hag), oleh KJV, NIV dan RSV menerjemahkannya menjadi study (belajar), sedangkan NAS menerjemahkannya devotion (kesetiaan). Ada perbedaan penerjemahan dari kata la hag, bila dilihat dari makna kata study dan devotion maka Study memiliki pengertian belajar dari buku untuk mendapat pengetahuan. Dalam proses belajar tersebut ada unsur kesetiaan (kecenderungan) terhadap objek belajar oleh subjek belajar. Pengkhotbah memberi peringatan dengan tegas kepada pembaca bahwa belajar (menekankan intelektualisme) merupakan kesia-siaan. ${ }^{24}$ Pengkhotbah belajar namun semuanya terbatas dan hanya hikmat dari Tuhan yang tidak terbatas.

Jadi study lebih menekankan pada ranah kognitif. Sementara ranah afektif dan psikomotorik dikesampingkan. Hal ini terlihat dari penegasan dari Pengkhotbah bahwa study dalam konteks ini merupakan kesia-siaan. Karena pengetahuan hanya sebatas diketahui, diingat akan tetapi tidak diterapkan dalam kehidupan sehari-hari. Tidak ada perubahan perilaku yang nampak, secara khusus seperti yang diharapkan Tuhan.

Jadi makna belajar dalam Perjanjian Lama memiliki dua pengertian yaitu pertama, kata belajar menggunakan kata Ibrani לְֵ (law-mad) dalam bahasa Inggris learn (belajar) adalah kegiatan seseorang untuk mempelajari, mendalami, memahami objek belajar secara terus-menerus yang disertai dengan latihan fisik dan mempraktikkan apa yang telah dipelajari sampai menguasai/ahli di bidang itu. Subjek belajar juga sampai pada pemahaman atau kematangan spiritual yang matang. ${ }^{25}$ Hasil belajar adalah terjadinya perubahan perilaku, karakter, sikap (afektif), pola pikir (kognitif/pengetahuan), mampu menerapkannya dalam kehidupan sehari-hari (psikomotorik) dan spiritual yang baik.teladan

\footnotetext{
${ }^{24}$ Donal Guthhrie, Tafsiran Alkitab Masa Kini 2, (Jakarta: Yayasan Komunikasi Bina Kasih/OMF, 1998), 348.

${ }^{25}$ Kata "belajar" dalam (Ul 14:23;17:19;18:9; 31:12; 31:13, Maz 106:35, 119:7; 71, 73, Yes. 1:17; 2:4; Pkh. 12:12, Yes. 26:9, 10; Yer. 12:16; Yeh. 19:3, 6; Mik. 4:3) berasal dari kata לִֵמֵ (law-mad), dalam konteks Perjanjian Lama subjek belajar tidak hanya belajar untuk mendapatkan pengetahuan, perubahan sikap, dan kemampuan melakukan apa yang dipelajari namun semuanya itu disertai dengan kerohanian yang bertumbuh kepada Tuhan atau takut akan Tuhan.
} 
Kedua, kata belajar menggunakan kata Ibrani לִ לִ (la hag) Study (belajar) adalah kegiatan mempelajari, mendalami pengetahuan dari buku-buku dan kecenderungan subjek belajar hanya untuk mendapatkan pengetahuan saja. Kecenderungan ini sampai kepada kesetiaan dalam menjunjung tinggi pengetahuan tanpa memaknai pengetahuan tersebut dalam tindakan nyata dalam kehidupan. Jadi study adalah proses belajar yang hanya mengumpulkan pengetahuan dari buku-buku atau kitab saja. Belajar di sini hanya menyentuh pada ranah kognitif.

\section{Tujuan belajar dalam Perjanjian Lama}

Jika dilihat dari setiap ayat dalam kitab (Ul. 14:23; 17:19;18:9; 31:12; 31:13, Maz. 106:35, 119:7; 71, 73, Pkh. 12:12, Yes. 1:17; 2:4; 26:9, 10; Yer. 12:16; Yeh. 19:3, 6; Mik. 4:3) maka kita akan melihat bahwa tujuan belajar dalam Perjanjian Lama yaitu:

1. Untuk mendapatkan pengetahuan yang benar tentang pribadi Allah secara benar. Setiap orang Israel harus mengenal pribadi Allah dengan benar, sebab mereka hidup dikelilingi oleh bangsa-bangsa yang tidak mengenal Allah yang benar.

2. Belajar bertujuan untuk memahami dan sampai mampu melakukan (hidup taat) ketetapan-ketetapan Allah. Supaya kehidupan bangsa Israel teratur (kudus) dan berkenan di hadapan Allah. Mereka belajar taat dan setia kepada Allah. Bahkan setiap orang Israel belajar dan diajar sampai taraf taat dan setia dengan segenap hati, dengan segenap jiwa, dengan segenap akal budi, dan dengan segenap kekuatan.

3. Belajar bertujuan untuk mengasihi Allah. Mengasihi Allah artinya setia dan taat melakukan setiap perintah-perintah-Nya. Jadi belajar dilakukan untuk lebih memahami bahwa Tuhan telah memberi teladan kasih. ${ }^{26}$ Oleh karenanya bangsa Israel harus mengasihi Allah, menuruti kehendak-Nya, dan setia beribadah ${ }^{27}$ kepada Allah.

${ }^{26}$ Hendro Hariyanto Siburian, STUDI EKSPOSISI TANGGUNG JAWAB SUAMI ISTRI MENURUT EFESUS 5:22-33 DAN APLIKASINYA BAGI KELUARGA KRISTEN MASA KINI (Tawangmangu: Sekolah Tinggi Teologi Tawangmangu, 2013), 26, https://doi.org/10.31219/osf.io/kdjh2.

${ }^{27}$ Beribadah merupakan bentuk kasih umat kepada Tuhan dengan aktivitas memuji, memuliakan dan mengagungkan Allah. Beribadah juga harus diterapkan dalam kehidupan sehari-hari yang ditandai dengan hidup saleh atau hidup benar sesuai Firman Tuhan. 
4. Belajar bertujuan mengembangkan kasih kepada sesama manusia. Mengasihi sesama manusia artinya ada tindakan menghargai dan menghormati sesama manusia, mengasihi tanpa syarat (agape), hidup saling tolong menolong, saling membangun satu sama lain dalam teguran dan nasehat. Secara khusus konteks bangsa Israel sebagai subjek belajar, mereka harus hidup dalam kasih dan tolong menolong sesama bangsa Israel sesuai dengan sepuluh hukum taurat.

5. Belajar dalam Perjanjian Lama bertujuan untuk memahami dan mengerti visi Allah dalam kehidupan setiap orang Israel, yaitu tujuan keselamatan dan menjadi berkat bagi bangsa-bangsa asing. Materi ajar didapat dari pengelaman generasi terdahulu bangsa Israel.

6. Belajar bertujuan mendapatkan pengetahuan, wawasan dan hikmat.

7. Menurut Kaster ada dua tujuan belajar bagi bangsa Israel, yaitu pertama, untuk mengerti sejarah bangsa Israel sebagai bangsa yang menerima janji-janji Allah yaitu keselamatan dan berkat-berkat kehidupan, kedua, belajar etika kehidupan yang sesuai dengan hukum taurat Allah sehingga bangsa Israel dapat menikmati hidup bahagia di dunia. ${ }^{28}$ Bangsa Israel "belajar" (learn) baik dari buku-buku maupun pengalaman dari para leluhur bahkan pengalaman hidup mereka sendiri bahwa Tuhan adalah sang pencipta dan yang memelihara kehidupan. Israel harus "learn" akan semua ketetapan Tuhan, bukan hanya belajar (study) semata-mata. karena Study merupakan kesia-siaan belaka.

Jadi belajar dalam Perjanjian Lama bertujuan untuk mengembangkan cinta kasih kepada Tuhan, memiliki pengetahuan yang benar akan ketetapan-ketetapan Tuhan sampai mampu melakukannya dan mengajarkannya. Jadi sangat jelas tujuan belajar adalah menghasilkan seseorang yang memiliki nilai-nilai baik, luhur, benar, karakter, dan indah untuk kehidupan sesuai kehendak Tuhan.

\section{Implementasi Belajar Dalam Perjanjian Lama Bagi Pendidikan Agama Kristen Masa Kini}

Implementasi dari makna kata belajar dalam Perjanjian Lama di atas dapat adalah sebagai berikut:

\footnotetext{
${ }^{28}$ Harianto GP, Pendidikan Agama Kristen Dalam Alkitab dan Dunia Pendidikan Masa Kini, (Yogyakarta: Andi Offset, 2016), 28.
} 
1. Dalam proses belajar yang menjadi materi ajar adalah Firman Tuhan. Secara khusus dalam Pendidikan Agama Kristen harus menekankan pembelajaran pada Firman Tuhan. Firman Tuhan menjadi sumber utama materi ajar dalam pendidikan agama Kristen. Melalui Firman Tuhan peserta didik akan menemukan siapa pribadi Allah yang sebenarnya. Sebab tidak ada referensi lain yang menjelaskan dengan rinci pribadi Allah yang benar selain Firman Tuhan (Alkitab). Pendidikan agama Kristen harus memastikan bahwa peserta didiknya belajar memiliki hubungan pribadi dengan Alla, sehingga terbangun spiritualitas yang kuat dan kokoh dalam setiap pribadi peserta didik.

2. Belajar harus menjadi gaya hidup setiap peserta didik Kristen. Proses belajar harus dilakukan secara terus-menerus sepanjang hidup. Tidak ada kata berhenti dalam belajar, belajar bagaimana hidup sebagai umat Tuhan supaya menjadi berkat bagi semua orang. Belajar taat dan setia kepada Tuhan dalam segala aspek kehidupan. Pendidikan agama Kristen membangun kurikulum pendidikan sedemikian rupa bagi subjek belajar mendalami dan memahami serta melakukan dalam ketaatan dan kesetiaan hukum-hukum Tuhan (Firman Tuhan). Melalui pendidikan agama Kristen proses belajar ditujukan untuk menuntun peserta didik untuk taat dan setia dengan segenap hati, dengan segenap jiwa, dengan segenap akal dan pikiran, dan dengan segenap kekuatan kepada Tuhan Yesus.

3. Belajar dalam mengembangkan cinta kasih terhadap sesama manusia. Pendidikan agama Kristen harus mengembangkan gaya belajar praktik dalam cinta kasih terhadap sesama manusia. Peserta didik belajar mengasihi setiap orang, seperti Yesus mengasihi semua orang. Dengan dasar demikian maka akan terbangun rasa cinta kasih dan kepedulian terhadap semua orang.

4. Belajar dilakukan untuk tujuan membangun manusia secara utuh. Dalam pendidikan agama Kristen, belajar ditujukan untuk membangun manusia secara utuh, baik secara rohani dan jasmani. Membangun manusia dalam hubungan yang intim dengan Tuhan. Membangun manusia sehingga mampu mengendalikan diri, membangun manusia memiliki kepribadian (sikap yang baik, karakter, watak, akhlak, integritas) yang baik. Belajar untuk membangun manusia seutuhnya secara pengetahuan dan keterampilan. 


\section{Kesimpulan}

Belajar adalah perubahan tingkah laku sebagai hasil dari perbuatan belajar yang terjadi secara sadar, bersifat berkelanjutan dan sesuai fungsinya, bersifat positif dan aktif, bersifat konstan, memiliki tujuan yang jelas, serta mencakup seluruh aspek tingkah laku subjek belajar.

Dalam Perjanjian Lama kata belajar disebutkan dalam dua kata yang memiliki pengertian yang berbeda yaitu: pertama kata לִ (law-mad) learn (belajar) adalah kegiatan seseorang untuk mempelajari, mendalami, memahami objek belajar secara terus-menerus yang disertai dengan latihan fisik dan mempraktikkan apa yang telah dipelajari sampai menguasai/ahli di bidang itu. Kedua, Kata לִ (la hag) Study (belajar) adalah kegiatan mempelajari, mendalami pengetahuan dari buku-buku dengan tujuan hanya untuk mendapatkan pengetahuan saja. Dalam pendidikan agama Kristen, belajar merupakan keharusan bagi setiap peserta didik. Peserta didik dituntut jangan puas hanya sampai pada (la hag, study) upaya mendapatkan pengetahuan semata-mata, melainkan harus sampai kepada menerapkan/mengajarkan (law-mad) learn pengetahuan tersebut dalam kehidupan sehari-hari. Peserta didik harus sampai kepada pengalaman pribadi bersama Tuhan. Yang dibuktikan dengan taat dan setia kepada Firman Tuhan, yakni mengasihi Tuhan dan mengasihi sesama manusia. Karena apapun yang kita pelajari hanya untuk hormat dan kemuliaan bagi Tuhan.

\section{Daftar Pustaka}

\section{LAI, Alkitab.}

Djamarah, S.B., “Psikologi Belajar”, Yogyakarta: Rineka Cipta, 2000.

E. Hill, Andrew dan John H. Walton., "Survey Perjanjian Lama" Malang: Penerbit Gandum Mas. 2008.

Guthrie, Donald., "Tafsiran Alkitab Masa Kini 1", Jakarta: Yayasan Komunikasi Bina Kasih/OMF. 1992.

------. “Tafsiran Alkitab Masa Kini 2”. Jakarta: Yayasan Komunikasi Bina Kasih/OMF, 1991.

GP., Harianto, "Pendidikan Agama Kristen Dalam Alkitab dan Dunia Pendidikan Masa Kini”, Yogyakarta: Andi Offset, 2016. 
Hill, Andrew E. dan John H. Walton, "Survey Perjanjian Lama”, Malang: Penerbit Gandum Mas, 2008.

Mahmud, H., "Psikologi Pendidikan”, Bandung: CV Pustaka Setia, 2012.

M. Thobroni., "Belajar dan Pembelajaran (teori dan praktik)”, Yogyakarta: Ar-Ruzz Media. 2016.

Reber, Arthur S., The Penguin Dictionary of Psychology: edisi 2010 terjemahan, (New York: Penguin Book, 2001.

Siburian, Hendro Hariyanto. "Implementasi Kesatuan dan Kerendahan Hati

Jemaat Berdasarkan Filipi 2:1-11 Di Kalangan Jemaat Gereja Pengharapan Allah Indonesia Surakarta." Sekolah Tinggi Teologia Berita Hidup. Sekolah Tinggi Teologia Berita Hidup, 2018. https://doi.org/10.31219/osf.io/adfbs.

—. STUDI EKSPOSISI TANGGUNG JAWAB SUAMI ISTRI MENURUT EFESUS 5:22-33 DAN APLIKASINYA BAGI KELUARGA KRISTEN MASA KINI. Tawangmangu: Sekolah Tinggi Teologi

Tawangmangu, 2013. https://doi.org/10.31219/osf.io/kdjh2.

Siburian, Hendro Hariyanto, dan Arif Wicaksono. "Makna Belajar Dalam Perjanjian Lama dan Implementasinya Bagi PAK Masa Kini.” Fidei:

Jurnal Teologi Sistemati dan Praktika 2, no. 2 (2019): 207-26.

Subagyo, Andreas B., "Pengantar Riset Kuantitatif dan Kualitatif".

Bandung: Yayasan Kalam Hidup. 2004.

Simajuntak, Junihot M., "Belajar Sebagai Identitas Dan Tugas Gereja”, Jurnal Jaffray, Vol. 16, No. 1, 2018.

Slameto, "Belajar dan Fakto-Faktor Yang Mempengaruhinya”, Jakarta: PT Rineka Cipta, 1995.

Sukmadinata, Nana Syaodih., "Metode Penelitian Pendidikan”, Bandung: PT Remaja Rosdakarya, 2008.

Aplikasi SABDA (OLB versi Indonesia) Versi 4.11.02 Copyright (c) 19922011

PC Study Bible Version 5 for Windows, Cpyright 1988-2007, Biblesoft, inc BibleWorks versi 8 copyright (c) 2009 for Windows https://id.oxforddictionaries.com/terjemahkan/inggris-indonesia/learn http://www.kompasiana.com/audiaaa/studying-is-bored-learning-is

fun_55c3175bac92737814471a0a

Yusra Firdaus, https://hellosehat.com/hidup-sehat/tahapan-perkembanganotak-manusia/.

http://kbbi.web.id 
